\section{Mass Spectrometry Highlights of the 22nd Annual FACSS Meeting}

O. David Sparkman

4045 Eagle Ridge Drive, Antioch, California, USA

The 22nd Annual Conference of the Federation of Analytical Chemistry and Spectroscopy Societies (FACSS XXII) was held in Cincinnati, Ohio, October 15-20, 1995. The location of this meeting changes from year to year. Richard E. Browner, Regents Professor, Georgia Institute of Technology, who is one of the meeting organizers, said there were 1550 registrants as of Wednesday afternoon. There were 991 presentations ( 879 oral and 112 posters). These presentations were given in 95 different half-day symposia, 14 of which focused on mass spectrometry, with 7 of these that addressed the analysis of inorganic substances. This is a significant emphasis on inorganic mass spectrometry. Dr. Browner said that FACSS was trying to emphasize mass spectrometry, especially the inorganic area. He felt this supplemented the ASMS meeting. With ASMS in June and FACSS in October, the two meetings do not compete with one another.

The meeting, held in the Cincinnati Convention Center, hosted a small instrument show with about 50 vendors.

At this year's FACSS meeting, George C. Stafford (Finnigan Corporation) was honored with the 1995 Anachem Award for his accomplishments in negative ion detection and quadrupole ion trap mass spectrometry in two half-day symposia organized by J. Throck Watson of Michigan State University.

Anachem is a regional analytical chemistry discussion group in Detroit, Michigan. It was started in 1942 with participants from Detroit's industrial community, Michigan State University, University of Michigan, and Wayne State University. The group has presented this award for outstanding contributions in analytical chemistry since 1952 and count at least one Nobel laureate who has received this award. The 44th annual award was presented by Dr. Keith Olson.

The first symposium focused on negative ion mass spectrometry with presentations by Donald F. Hunt (Dr. Stafford's major professor during the development of pulsed positive-negative ion detection at the University of Virginia) on the early development of negative ion mass spectrometry, Mike Story (Finnigan Corporation) on Dr. Stafford's commercialization of negative ion mass spectrometry, Rodger L. Foltz (University of Utah) on the use of negative ion mass spectrometry in the analysis of drugs, N. Xu (student of Dr. J. T. Watson at MSU) on the analysis of anabolic steroids by negative ion mass spectrometry, K. A.
Harrison (an associate of R. C. Murphy at National Jewish Center) on negative ionization techniques for phospholipid analysis, and Ronald A. Hites (Indiana University) on electron capture ionization mass spectrometry in environmental chemistry. Dr. Stafford is well known for his developments and patents in the area of negative ion mass spectrometry. He is the developer of the pulsed positive-negative ion chemical ionization (PPNICI) detector and the conversion dynode used in conjunction with electron multipliers for detection of negative ions.

The second symposium was on quadrupole ion trap mass spectrometry. Dr. Stafford's accomplishments in this area of mass spectrometry are well recognized. This symposium featured talks by R. Graham Cooks (Purdue University) on the simulation and experimentation of ion motion in quadrupole ion traps, Peter $\mathrm{H}$. J. Dawson (National Research Center, Canada) on the early development of the quadrupole ion trap-The Dark Ages, John F. J. Todd (University of Kent) on the Middle Ages of ion trap development, P. H. Hemberger (Los Alamos National Laboratory) on the trace environmental analyses by using quadrupole ion trap mass spectrometers, Jae C. Schwartz (Finnigan Corporation) on Dr. Stafford's work in ion trap development at Finnigan, and Norman A. Yates (University of Virginia) on the use of ion trap mass spectrometry in peptide sequencing. The symposium concluded with the presentation of the award to Dr. Stafford and his presentation entitled Positive and Negative Observations (and Some Traps) along the Technology Development Road.

One interesting fact came out of these presentations other than the technical issues. Dr. Dawson published a book in 1976 entitled Quadrupole Mass Spectrometry and Its Applications that is considered to be one of the most significant pieces of work for those in quadrupole mass spectrometry. It was out of print and unavailable for many years, but has just been reprinted as a copy of the original with no changes by the American Institute of Physics.

In addition to the ion trap presentation for the Anachem Award Symposium, Dr. Cooks hosted a halfday symposium on ion trap mass spectrometry that featured other well-known contributors such as Ray March, who has just published a trilogy on ion trap mass spectrometry with John Todd (Practical Applications of Ion Trap Mass Spectrometry, Vols. I, II, and III; CRC Press, Boca Raton, FL). Richard Yost (Florida State University) also made a presentation.

This symposium ended with a very good discussion on a number of issues that had been raised regarding different aspects of ion trap mass spectrometry. These 
issues included the future of portable gas chromatographs-mass spectrometers, implications of tandem time-of-flight/quadrupole ion trap mass spectrometers, and the possibilities of matrix-assisted laser desorption ionization and the ion trap mass spectrometer.

The following list gives the mass spectrometry symposia presented at the 1995 FACSS Meeting:

Plasma Source MS-Surely There are Alternatives to Quadrupole-ICP-MS

G.M. Hieftje, University of Indiana

Innovations and Applications of Biological Mass Spectrometry

Michelle Buchanan, Oak Ridge

ICP-MS New Challenges and Applications

R. M. Hutton, Fisons Instruments

New Ideas in Chromatography/Mass Spectrometry W. L. Budde, USEPA

Process Monitoring with Mass Spectrometry and
Other Techniques

C. Hassell, DuPont

Glow Discharge Mass Spectrometry II

M. R. Winchester, NIST

Anachem Award Symposium-Negative Ion Theme J. T. Watson, Michigan State University

Anachem Award Symposium-Ion Trap Theme

J. T. Watson, Michigan State University

Ion Trap Mass Spectrometry

G. Cooks, Purdue University

ICP-MS: Chromatographic Detection

New Developments and Novel Applications of Matrix-Assisted Laser Desorption Ionization Mass Spertrometry (MALDI)

K. K. Murray, Emory University

ICP-MS: Instrumentation and Fundamentals

A. Montaser, George Washington University ICP-MS: Automation and Applications

New Mass Spectrometric Methods for Solids and Energetic Materials 